\title{
PENGARUH CAKUPAN IMUNISASI CAMPAK TERHADAP INCIDENCE RATE PENYAKIT CAMPAK DI INDONESIA TAHUN 2016
}

\author{
Satriya Wijaya \\ Program Studi S1 Ilmu Kesehatan Masyarakat \\ Fakultas Kesehatan, Universitas Nahdlatul Ulama Surabaya \\ Email: swijaya7@unusa.ac.id or swijaya7@gmail.com
}

\begin{abstract}
Immunization has proven to be one of the most important public health efforts. The immunization program has shown remarkable success and is a very costeffective effort in preventing infectious diseases (MOH, 2003). Immunization has also saved so many lives compared to other public health efforts. Very important role of measles immunization in reducing child mortality, so measles immunization become one of indicator in achieving fourth goal of MDGs that is decrease child mortality rate. In this case, what is seen is the proportion of one-year-old children who get measles immunization (WHO, 2014 in the Ministry of Health RI, 2014).

The design of this study was cross-sectional with a retrospective approach. The target of this research is all people in Indonesia who are positive for measles. The data used are secondary data derived from the Health Profile of Indonesia Year 2015, to describe the implementation of measles control program in Indonesia in 2016. The variables measured in this study include the success rate of measles immunization coverage in Indonesia in 2016 and the extent of the decrease in measles incidence rate as the impact of measles immunization coverage program in Indonesia in 2016. The overall data used in this study is obtained from data health that is reported on the Health Profile of Indonesia Year 2015. Statistical method used is parametric statistics with the test used is Simple Linear Regression with the help of computer software that is SPSS to help analyze the regression results between the dependent variable and independent variables.

The results showed that all infants in Jambi, West Nusa Tenggara, South Sumatera, Central Java and Lampung provinces had measles immunization. Meanwhile, the lowest coverage is Papua with $62.40 \%$, followed by Aceh with $69.60 \%$ and West Papua with $73.69 \%$. Then the result of analysis by using simple linear regression statistic test showed that the measles immunization coverage program has an effect on the incidence rate of measles disease with significance value equal to 0,035 . In addition, from the research results obtained information that an effective way to prevent measles is the immunization of children under the age of 9 months ( $<1$ year). During the period 2000-2013, measles immunization succeeded in reducing 15.6 million (75\%) deaths from measles in Indonesia.
\end{abstract}

Keywords: Measles Immunization Coverage, Measles Disease, Incidence Rate Measles

Abstrak: Imunisasi telah terbukti sebagai salah satu upaya kesehatan masyarakat yang sangat penting. Program imunisasi telah menunjukkan keberhasilan yang luar biasa dan merupakan usaha yang sangat hemat biaya dalam mencegah penyakit menular (Depkes RI, 2003). Imunisasi juga telah berhasil menyelamatkan begitu banyak 
kehidupan dibandingkan dengan upaya kesehatan masyarakat lainnya. Sangat pentingnya peranan imunisasi campak dalam menurunkan angka kematian anak, sehingga imunisasi campak menjadi salah satu indikator dalam mencapai tujuan MDGs yang keempat yaitu menurunkan angka kematian anak. Dalam hal ini, yang dilihat yaitu proporsi anak usia satu tahun yang mendapat imunisasi campak (WHO, 2014 didalam Kemenkes RI, 2014).

Desain penelitian ini adalah cross-sectional dengan pendekatan retrospektif. Sasaran dalam penelitian ini adalah seluruh masyarakat di Indonesia yang positif terkena campak. Data yang digunakan adalah data sekunder yang berasal dari Profil Kesehatan Indonesia Tahun 2015, untuk menggambarkan pelaksanaan program pengendalian penyakit campak di Indonesia pada Tahun 2016.

Variabel yang diukur dalam penelitian ini meliputi tingkat keberhasilan pelaksanaan program cakupan imunisasi campak di Indonesia pada tahun 2016 dan sejauh mana penurunan incidence rate campak sebagai dampak pelaksanaan program cakupan imunisasi campak di Indonesia pada tahun 2016. Data secara keseluruhan yang digunakan dalam penelitian ini diperoleh dari data kesehatan yang dilaporkan pada Profil Kesehatan Indonesia Tahun 2015. Metode statistik yang digunakan adalah statistik parametrik dengan uji yang digunakan adalah Regresi Linear Sederhana dengan bantuan perangkat lunak computer yaitu SPSS untuk membantu menganalisis hasil regresi antara variabel terikat dan variabel bebas.

Dari hasil penelitian menunjukkan bahwa seluruh bayi di Provinsi Jambi, Nusa Tenggara Barat, Sumatera Selatan, Jawa Tengah, dan Lampung telah mendapatkan imunisasi campak. Sedangkan provinsi dengan cakupan terendah yaitu Papua sebesar 62,40\%, diikuti oleh Aceh sebesar 69,60\% dan Papua Barat sebesar 73,69\%. Kemudian hasil analisis dengan menggunakan uji statistik regresi linear sederhana menunjukkan bahwa program cakupan imunisasi campak berpengaruh terhadap terjadinya terhadap incidence rate penyakit campak dengan nilai signifikansi sebesar 0,035 . Selain itu, dari hasil penelitian didapat informasi bahwa cara yang efektif untuk mencegah penyakit campak yaitu dengan imunisasi balita pada usia 9 bulan $(<1$ tahun). Selama periode 2000-2013, imunisasi campak berhasil menurunkan 15,6 juta (75\%) kematian akibat campak di Indonesia.

\section{Kata Kunci : Cakupan Imunisasi Campak, Penyakit Campak, Incidence Rate Campak}

\section{PENDAHULUAN}

Imunisasi atau kekebalan tubuh terhadap ancaman penyakit adalah tujuan utama dari pemberian vaksinasi. Dan imunisasi telah terbukti sebagai salah satu upaya kesehatan masyarakat yang sangat penting. Program imunisasi telah menunjukkan keberhasilan yang luar biasa dan merupakan usaha yang sangat hemat biaya dalam mencegah penyakit menular (Depkes RI, 2003). Imunisasi juga telah berhasil menyelamatkan begitu banyak kehidupan dibandingkan dengan upaya kesehatan masyarakat lainnya.

Menurut Kemenkes RI (2015), campak merupakan penyakit endemik di negara berkembang termasuk Indonesia. Di Indonesia, campak masih menempati urutan ke-5 penyakit yang menyerang terutama pada bayi dan balita. Pada tahun 2014 di Indonesia ada 12.943 kasus campak. Angka ini lebih tinggi dibandingkan pada tahun 2013 sebanyak 11. 521 kasus. Jumlah kasus meninggal sebanyak 8 kasus yang terjadi di 5 
provinsi yaitu Riau, Jambi, Sumatera Selatan, Kepulauan Riau dan Kalimantan Timur. Incidence rate (IR) campak pada tahun 2014 sebesar 5,13 per 100.000 penduduk. Angka ini meningkat dibandingkan tahun 2013 yang sebesar 4,64 per 100.000 penduduk. Kasus campak terbesar pada kelompok umur 59 tahun dan kelompok umur 1-4 tahun sebesar $30 \%$ dan $27,6 \%$.

Sangat pentingnya peranan imunisasi campak dalam menurunkan angka kematian anak, sehingga imunisasi campak menjadi salah satu indikator dalam mencapai tujuan MDGs yang keempat yaitu menurunkan angka kematian anak. Dalam hal ini, yang dilihat yaitu proporsi anak usia satu tahun yang mendapat imunisasi campak (WHO, 2014 didalam Kemenkes RI, 2014).

\section{METODE PENELITIAN}

Desain penelitian ini adalah crosssectional dengan pendekatan retrospektif. Data yang digunakan adalah data sekunder yang berasal dari Profil Kesehatan Indonesia Tahun 2015, untuk menggambarkan pelaksanaan program pengendalian penyakit campak di Indonesia pada Tahun 2016.

Variabel yang diukur dalam penelitian ini meliputi variabel bebas atau independent dan variabel terikat atau dependent dengan detail sebagai berikut :

1. Variabel bebas (independent), yaitu tingkat keberhasilan pelaksanaan program cakupan imunisasi campak di Indonesia pada tahun 2016.

2. Variabel terikat (dependent), yaitu sejauh mana penurunan incidence rate campak sebagai dampak pelaksanaan program cakupan imunisasi campak di Indonesia pada tahun 2016.

Data secara keseluruhan yang digunakan dalam penelitian ini diperoleh dari data kesehatan yang dilaporkan pada Profil Kesehatan Indonesia Tahun 2015.

Metode statistik yang digunakan adalah statistik parametrik dengan uji yang digunakan adalah Regresi Linear Sederhana dengan bantuan perangkat lunak komputer yaitu SPSS untuk membantu menganalisis hasil regresi antara variabel terikat dan variabel bebas.

\section{HASIL DAN PEMBAHASAN}

Gambaran Pelaksanaan Program Pengendalian Penyakit Campak di Indonesia Tahun 2016

Menurut provinsi, terdapat empat belas provinsi yang telah berhasil mencapai target $90 \%$ seperti yang disajikan pada gambar berikut ini : 


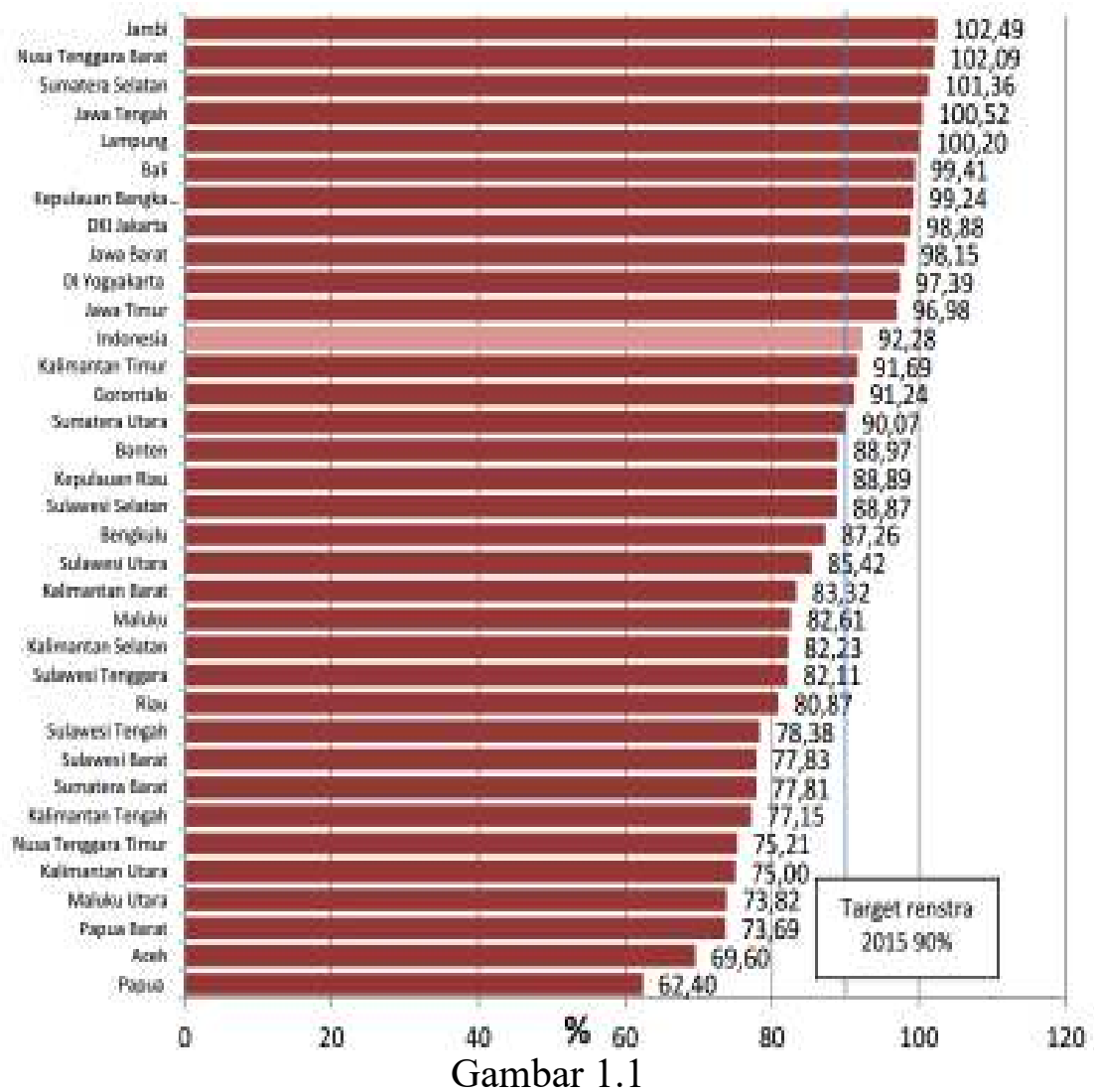

Persentase Cakupan Imunisasi Campak Pada Bayi Menurut Provinsi Tahun 2015

Pada Gambar 1.1 di atas dapat diketahui bahwa seluruh bayi di Provinsi Jambi, Nusa Tenggara Barat, Sumatera Selatan, Jawa Tengah, dan Lampung telah mendapatkan imunisasi campak. Sedangkan provinsi dengan cakupan terendah yaitu Papua sebesar 62,40\%, diikuti oleh Aceh sebesar 69,60\% dan Papua Barat sebesar 73,69\% (Kemenkes RI., 2015).
Gambaran Kejadian Penyakit Campak di Indonesia Pada Tahun 2016

Penyakit campak disebabkan oleh virus campak golongan Paramyxovirus. Penularan dapat terjadi melalui udara yang telah terkontaminasi oleh droplet (ludah) orang yang telah terinfeksi. Sebagian besar kasus campak menyerang anak-anak usia pra sekolah dan usia SD. Jika seseorang pernah menderita campak, maka dia akan mendapatkan kekebalan terhadap penyakit tersebut seumur hidupnya. 


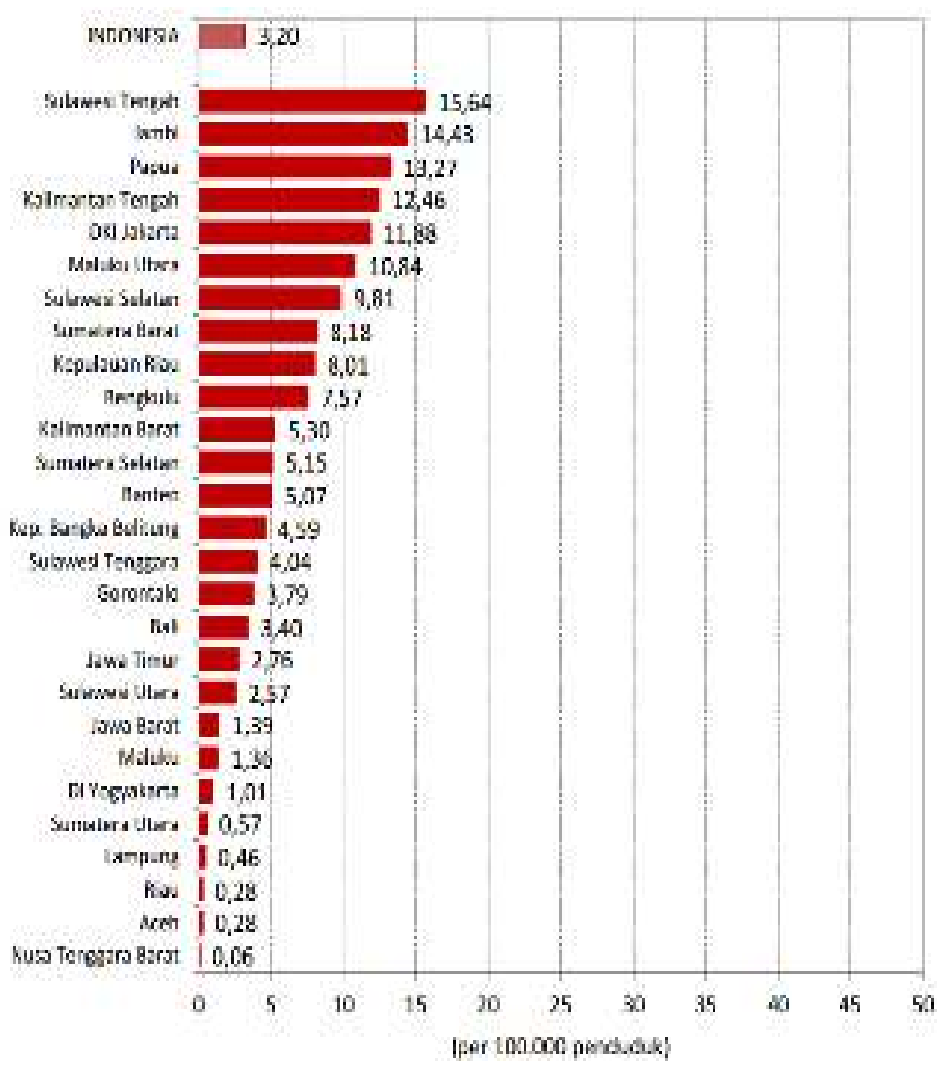

Gambar 1.2

Incidence Rate (IR) Campak Per 100.000 Penduduk Menurut Provinsi Di Indonesia

Tahun 2015

Gambar 1.2 di atas menyajikan Incidence Rate (IR) campak menurut provinsi. Nusa Tenggara Barat, Aceh, dan Riau merupakan provinsi dengan IR campak terendah. Sedangkan Sulawesi Tengah, Jambi dan Papua merupakan provinsi dengan Incidence Rate (IR) campak tertinggi.

Menurut kelompok umur, proporsi kasus campak dapat diamati pada Gambar 4.3 berikut ini yang memperlihatkan proporsi kasus campak per 100.000 penduduk menurut kelompok umur di Indonesia.

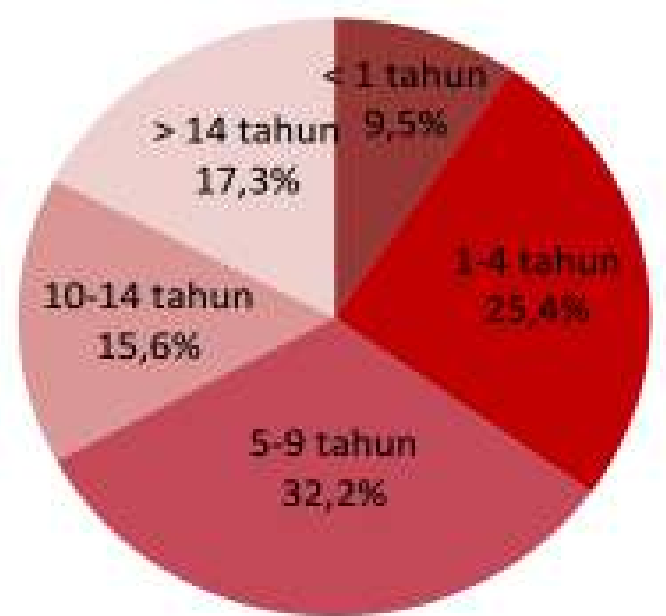

Gambar 1.3

Proporsi Kasus Campak Per 100.000

Penduduk

Menurut Kelompok Umur di Indonesia Tahun 2015

Menurut kelompok umur, proporsi kasus campak terbesar terdapat pada kelompok umur 5-9 
tahun dan kelompok umur 1-4 tahun dengan proporsi masing-masing sebesar 32,2\% dan 25,4\%. Namun jika dihitung rata-rata umur tunggal, kasus campak pada bayi $<1$ tahun merupakan kasus yang tertinggi, yaitu sebanyak 778 kasus (9,5\%) (Kemenkes RI., 2015).

\section{Pengaruh Program Cakupan Imunisasi Campak Terhadap Incidence Rate Penyakit Campak di Indonesia Pada Tahun 2016}

Dalam menjawab pengaruh dari program cakupan imunisasi campak terhadap incidence rate penyakit campak, dapat diamati pada hasil analisis berikut ini dengan menggunakan uji statistik regresi linear sederhana. Berikut merupakan detail hasil analisis regresi linear sederhana beserta syarat-syarat penyertanya.

1. Hasil Uji Normalitas Data

Uji normalitas data digunakan untuk memenuhi asumsi dalam syarat pengujian regresi linear sederhana. Berikut ini hasil dari uji normalitas data dengan menggunakan Shapiro-Wilk Test.

Tabel 1.1. Hasil Uji Normalitas Data dengan Shapiro-Wilk Test

\begin{tabular}{|c|c|c|c|c|}
\hline No. & $\begin{array}{l}\text { Varia } \\
\text { bel }\end{array}$ & $\begin{array}{l}\text { Signifika } \\
\text { nsi }\end{array}$ & $\begin{array}{l}\text { Syar } \\
\text { at }\end{array}$ & $\begin{array}{l}\text { Keteran } \\
\text { gan }\end{array}$ \\
\hline 1. & $\begin{array}{l}\text { Imun } \\
\text { isasi } \\
\text { Cam } \\
\text { pak }\end{array}$ & 0,128 & \multirow[t]{2}{*}{$\begin{array}{l}> \\
0,05\end{array}$} & $\begin{array}{l}\text { Memenu } \\
\text { hi } \\
\text { asumsi } \\
\text { Normali } \\
\text { tas }\end{array}$ \\
\hline 3. & $\begin{array}{l}\text { Incid } \\
\text { ence } \\
\text { Rate } \\
\text { Cam } \\
\text { pak }\end{array}$ & 0,070 & & $\begin{array}{l}\text { Memenu } \\
\text { hi } \\
\text { asumsi } \\
\text { Normali } \\
\text { tas }\end{array}$ \\
\hline
\end{tabular}

Berdasarkan tabel diatas dapat diinformasikan bahwa seluruh variabel yang diteliti telah memenuhi asumsi syarat normalitas data. Oleh sebab itu, pengujian dapat dilanjutkan ke tahap berikutnya yaitu dengan uji regresi linear sederhana.

2. Hasil Uji Regresi Linear Sederhana

Pengaruh dari program cakupan imunisasi campak terhadap incidence rate penyakit campak dapat diamati pada hasil analisa berikut ini.

Tabel 1.2. Hasil Uji Regresi Linear Sederhana - Coefficients

\begin{tabular}{|l|l|l|l|l|}
\hline $\begin{array}{l}\text { N } \\
\text { o. }\end{array}$ & $\begin{array}{l}\text { Vari } \\
\text { abel }\end{array}$ & $\begin{array}{l}\text { Signif } \\
\text { ikansi }\end{array}$ & $\begin{array}{l}\text { Sy } \\
\text { ara } \\
\text { t }\end{array}$ & $\begin{array}{l}\text { Ketera } \\
\text { ngan }\end{array}$ \\
\hline 1. & $\begin{array}{l}\text { Cons } \\
\text { tant }\end{array}$ & 0,031 & $\begin{array}{l}< \\
0,0\end{array}$ & $\begin{array}{l}\text { Berpe } \\
\text { ngaruh }\end{array}$ \\
\cline { 1 - 3 } 2. & $\begin{array}{l}\text { Imun } \\
\text { isasi } \\
\text { Cam } \\
\text { pak }\end{array}$ & 0,035 & 5 & $\begin{array}{l}\text { Berpe } \\
\text { ngaruh }\end{array}$ \\
\hline
\end{tabular}

Berdasarkan tabel diatas, dapat diperoleh informasi bahwa variabel bebas, yaitu Imunisasi Campak mempunyai pengaruh terhadap incidence rate penyakit campak. Program cakupan imunisasi campak berpengaruh terhadap terjadinya terhadap incidence rate penyakit campak dengan nilai signifikansi sebesar 0,035 .

\section{SIMPULAN DAN SARAN}

\section{Simpulan}

a. Seluruh bayi di Provinsi Jambi, Nusa Tenggara Barat, Sumatera Selatan, Jawa Tengah, dan Lampung telah mendapatkan imunisasi campak. Sedangkan provinsi dengan cakupan terendah yaitu Papua sebesar 62,40\%, diikuti oleh Aceh sebesar 69,60\% dan Papua Barat sebesar 73,69\%.

b. Incidence Rate (IR) campak menurut provinsi. Nusa Tenggara 
Barat, Aceh, dan Riau merupakan provinsi dengan IR campak terendah. Sedangkan Sulawesi Tengah, Jambi dan Papua merupakan provinsi dengan IR campak tertinggi.

c. Imunisasi Campak mempunyai pengaruh terhadap incidence rate penyakit campak. Program cakupan imunisasi campak berpengaruh terhadap terjadinya terhadap incidence rate penyakit campak dengan nilai signifikansi sebesar 0,035 .

\section{Saran}

1. Cakupan imunisasi di Papua sebesar 62,40\%, Aceh sebesar 69,60\% dan Papua Barat sebesar 73,69\%. Untuk itu Pemerintah pusat harus mendorong komitmen Pemerintah daerah untuk mendukung pencapaian target nasional cakupan imunisasi campak melalui peningkatan peran Puskesmas dan jaring pelayanannya dalam bidang pengendalian penyakit menular khususnya penyakit campak.

2. Diharapkan adanya pengembangan penelitian lanjutan melalui rekayasa sosial budaya sehingga masyarakat Indonesia terutama di Papua, Aceh dan Papua Barat lebih bisa menyadari pentingnya preventif dengan imunisasi daripada mengobati penyakit campak.

\section{REFERENSI}

Profil Kesehatan Indonesia Tahun 2015. http://www.kemkes.go.id sitasi 23 September 2016.

Casaeri. 2003. Faktor Risiko Kejadian Campak Di Kabupaten Kendal tahun

2002. Semarang: Universitas Diponogoro.

Chandra, B. 2012. Kontrol Penyakit Menular Pada Manusia. Jakarta: EGC.
Depkes RI. 2000. Petunjuk Pelaksanaan Program Imunisasi. In: Dirjen PPM PLP, editor. Jakarta: Depkes RI.

Efriyanti, A. 2009. Faktor- Faktor Yang Berhubungan Dengan Cakupan

Imunisasi Campak Di Kabupaten Tegal. In. Edited by Semarang UN.

Frida, E. 2007. Faktor- Faktor Yang Berhubungan Dengan Kejadian Campak

Pada Balita Di Puskesmas Kumai Kabupaten

Kotawaringin Barat Kalimantan Tengah Tahun 2007. In. Edited by Nuswantoro UD. Semarang.

Giarsawan, N. 2014. Faktor Faktor Yang Mempengaruhi Kejadian Campak Wilayah Puskesmas Tejakula I Kecamatan Tejakula Kabupaten Buleleng Tahun 2012. Jurnal Kesehatan Lingkungan.Vol. 4, No.

November: 140-145.

Hasmi. 2012. Metode Penelitian Epidemiologi. Jakarta: Trans Info Media.

Kunoli, FJ. 2013. Pengantar Epidemiologi Penyakit Menular. Jakarta: Trans Info Media.

Mujiati, E. 2014. Faktor Risiko Kejadian Campak Pada Anak Usia 1-14 Tahun di Kecamatan Metro Pusat Propinsi Lampung Tahun 2013$2014 . \quad$ Universitas Sriwijaya Palembang.

Natalya, D. 2011. Analisis Kejadian Campak Pada Anak Balita Di Kelurahan

Tegal Sari Mandala III Kecamatan Medan Denai Tahun 2010. 
Nurani, DS. 2012. Gambaran Epidemiologi Kasus Campak di Kota Cirebon tahun 2004-2011 (Studi Kasus Data Surveilans Epidemiologi Campak Di Dinas Kesehatan Kota Cirebon). Jurnal Kesehatan Masyarakat, Vol 1, No 2:293-304.

Noor, NN. (nd). Pengantar Epidemiologi Penyakit Menular. Jakarta: Rineka Cipta.

Notoatmodjo, S. 2003. Prinsip Prinsip Dasar Ilmu Kesehatan Masyarakat. Jakarta: Rineka Cipta.

Notoatmodjo, S. 2007. Promosi Kesehatan dan Ilmu Perilaku. Jakarta: Rineka Cipta.

Notoatmodjo, S. 2010. Metodologi Penelitian Kesehatan. Jakarta: Rineka Cipta.

Sabri, L. dan Priyo, S. 2013. Statistik Kesehatan. Jakarta: Rajawali Pers.

Saepudin, M. 2011.Metode Penelitian Kesehatan Masyarakat. Jakarta: Trans Info Media.
Samet, JM. 2009. Adapting to Climate Change - Public Health. Adaptation-An Initiative of the Climate Policy Program. RFF.

Sastroasmoro, S. 2002.Dasar-Dasar Metodologi Penelitian Klinis. 2 ed. Jakarta: Sagung Seto.

Setyaningrum. 2013.Faktor Faktor Yang Berhubungan Dengan Kejadian Penyakit Campak di Wilayah Kerja Puskesmas Kecamatan Teras

Kabupaten Boyolali. In. Edited by Muhammadiyah U. Surakarta.

Siregar, K. 2002. Faktor Risiko Kejadian Campak Pada Anak Umur 9 bulan - 6 tahun Pada Saat KLB di Kabupaten Bogor tahun 2002. Depok:

Universitas Indonesia.

Slamet JS. 2011. Kesehatan Lingkungan. Yogyakarta : Gadjah Mada University Press.

Sumantri, A. 2011. Metodologi Penelitian Kesehatan. Jakarta: Kencana.

Wahab, S. 2002. Sistem Imun, Imunisasi, dan Penyakit Imun. Jakarta: Widya Medika. 